\title{
Effect of Sargassum polycystum extract on liver and kidney of diabetic rats
}

\section{Pengaruh ekstrak Sargassum polycystum terhadap hati dan ginjal tikus diabetes melitus}

\author{
Muhamad Firdaus*, Anies Chamidah, Annafi Riski Nurcholis, Siti Yulaikah, \\ Pangestuty Yeni Anggraeni, Widya Adi Suryanata, Denny Alghafihqi, Rendi \\ Hardiansyah \\ Program Studi Teknologi Hasil Perikanan, Fakultas Perikanan dan Ilmu Kelautan, \\ Universitas Brawijaya \\ Jalan Veteran, Malang - 65145
}

Submitted: 05-10-2017

Reviewed: 31-10-2017

Accepted: 27-11-2017

\begin{abstract}
ABSTRAK
Hiperglikemik diketahui mampu memicu pembentukan radikal bebas. Kereaktifan radikal bebas dapat mengakibatkan kerusakan fungsi dan struktur hati dan ginjal pada penyandang diabetes mellitus. Polifenol merupakan bioaktif yang dapat menurunkan kereaktifan radikal bebas. Polifenol diketahui juga terkandung dalam rumput laut cokelat. Salah satu rumput laut cokelat yang banyak terdapat di perairan Indonesia adalah Sargassum polycystum. Tujuan penelitian ini adalah untuk menguji ekstrak S. polycystum (ESP) dalam mengurangi kerusakan fungsi dan struktur hati dan ginjal pada tikus diabetes melitus. ESP didapatkan melalui pengeringan, penepungan, ekstraksi dengan metanol (1:3; $\mathrm{b} / \mathrm{v}$ ), pemekatan, degassing, dan pengeringan beku. Tikus strain Wistar jantan diinduksi menjadi diabetes dengan streptozotocin. Penelitian ini terbagi empat kelompok yaitu: normal, diabetes, diabetes + gliklasid dan diabetes + ESP. Perlakuan dalam penelitian dilaksanakan selama 45 hari. Kadar polifenol rumput laut, kadar malondialdehid (MDA), kadar serum glutamate piruvat transaminase (SGPT), kadar serum glutamate oksaloasetat transaminase (SGOT) dan kreatinin diukur dengan metode spektrofotometer, kadar glukosa darah ditentukan dengan glukometer, kadar insulin ditentukan dengan metode enzyme-linked immunosorbent assay (ELISA). Perubahan struktur hati dan ginjal dianalisis dengan metode pengecatan hematoksilin dan eosin. Hasil menunjukkan bahwa pemberian ESP pada tikus diabetes mampu menurunkan glukosa darah, kadar MDA pada hati dan ginjal, kadar SGPT dan SGOT hati, kadar kreatinin darah, meningkatkan kadar insulin dan memperbaiki struktur hati dan ginjal. Hasil ini mengindikasikan bahwa ESP dapat mengurangi kerusakan fungsi dan struktur hati dan ginjal pada tikus diabetes melitus.
\end{abstract}

Kata kunci: diabetes, polifenol, radikal bebas, Sargassum polycystum

\section{ABSTRACT}

Hyperglycemia has been known able to incuce the free radical formation. The reactivity of free radical can affect the dysfunction and structural adjustment on liver and kidney of the diabetic. Polyphenol is bioactive that able to ameliorate the reactivity of free radical. This substance is also contained in brown seaweed.

Penulis korespondesi:

Muhamad Firdaus

Prodi Teknologi Hasil Perikanan, Fakultas Perikanan dan Ilmu Kelautan, Universitas Brawijaya

Jl. Veteran Malang - 65145, Indonesia

Email:muhamadfir@ub.ac.id 
One of brown seaweeds that found on the Indonesia waters is Sargassum polycystum. The objective of this study was to evaluate the $S$. polycystum extract (SPE) to reduce the damage of the function and structure of liver and kidney in diabetic rats. SPE was obtained by drying, milling, extraction by methanol, concentrating, degassing by nitrogen gas, and finally freeze-drying, respectively. The male of rat strain Wistar was induced to diabetic by streptozotocin. This study was divided into four groups, i.e., normal, diabetic, diabetic + gliclazide and diabetic + SPE, respectively. The treatments of this experiment were executed for 45 days. The polyphenol content, malondialdehyde level, SGPT and SGOT levels, and creatinine levels were measured by the spectrophotometer, the blood glucose level was quantified by glucometer, and the insulin content was determined by ELISA method. The altering of the tissue structure was analyzed by staining method of hematoxylin and eosin. The result showed that the treatment of SPE on diabetic rats able to reduce the blood glucose level, malondialdehyde level of liver, and kidney, SGPT and SGOT level of liver, creatinine level of blood, and increase of insulin level and improve the liver, and kidney tissue profiles, respectively. These results indicate that SPE can reduce the damage of function and structure on liver and kidney of the diabetic rats.

Keywords: diabetes, free radical, polyphenol, Sargassum polycystum

\section{PENDAHULUAN}

Kondisi hiperglikemik yang berlangsung kronik dapat memicu terjadinya penyakit komplikasi diabetes. Penanganan dan biaya pengobatan komplikasi diabetes tergolong mahal dan membutuhkan waktu lama. Sebagian besar penyandang diabetes di daerah tropis yang berpenghasilan rendah memanfaatkan bahan-bahan alami (herbal) untuk penanganan penyakit komplikasi diabetes (Barde et $a l .$, 2015). Indonesia merupakan daerah tropis yang kaya akan bahan alam. Bahan-bahan alam telah lama diketahui dan banyak digunakan untuk menjaga kesehatan dan pengobatan, diantaranya untuk pengobatan diabetes (Firdaus, 2017).

Penyakit komplikasi yang ada pada tubuh penderita diabetes sangat terkait dengan reaktivitas radikal bebas. Keadaan hiperglikemik yang berlangsung kronis akan memicu kondisi stres oksidatif, yaitu keadaan dimana jumlah dan reaktivitas radikal bebas lebih dominan dari antioksidan tubuh (Kuyvenhofen and Meinders, 1999). Glukosa darah yang telah mengalami glikasi akan menjadi salah satu pembentuk spesies oksigen radikal. Hidroksil radikal adalah salah satu spesies oksigen radikal yang sangat reaktif untuk bereaksi dengan komponen membran sel dan akibatnya struktur sel akan rusak hingga fungsinyapun akan hilang (Jay et al., 2006).

Rumput laut cokelat adalah salah satu bahan alam yang banyak terdapat di perairan Indonesia, diantaranya adalah $S$. polycystum. Rumput laut ini diketahui mengandung florotanin, sejenis polifenol yang juga berkemampuan menurunkan glukosa darah dan beraktivitas antioksidan (Lee and Jeon, 2013). Polifenol adalah bioaktif yang beraktivitas penurun glukosa darah karena mampu menghambat aktivitas glukosidase dan amilase dan meningkatkan sekresi dan sensitivitas insulin (Bahadoran et al., 2013). Kemampuan bioaktif ini untuk mengurangi radikal bebas telah banyak dimanfaatkan sebagai bahan antioksidan pangan dan kesehatan (Fraga et al., 2010). Tujuan penelitian ini adalah untuk menguji ekstrak $S$. polycystum dalam mengurangi kerusakan fungsi dan struktur hati dan ginjal pada tikus diabetes mellitus.

\section{METODE PENELITIAN Alat dan Bahan}

Alat-alat yang digunakan dalam penelitian ini antara lain: Vacuum rotary evaporator (IKA RV10), glucometer (GlucoDr), spektrofotometer UV-Vis (Spectroquant Tipe Pharo 300), ELISA reader (BioRad 550) dan Mikroskop (Olympus BX41). Hewan coba yang digunakan dalam penelitian ini adalah tikus strain Wistar, jantan, berumur 2,5 bulan dengan berat badan 175-200 g. S. polycystum diperoleh dari perairan pulau Talango, Kabupaten Sumenep, Jawa Timur, pada bulan Februari-Maret 2016. Bahan kimia yang digunakan dalam penelitian antara lain: metanol p.a., floroglusinol, reagen 
follin-ciocalteu, $\mathrm{Na}_{2} \mathrm{CO}_{3} 5 \%$, gliklasid, streptozotocin (Bioworld), dan rat insulin ELISA kit (Bioassay Technology Laboratory No. E0707Ra, Shanghai China).

\section{Jalannya Penelitian}

Ekstrak dipersiapkan dan diperoleh melalui beberapa tahap, antara lain: pengeringan $S$. polycystum dibawah sinar matahari selama \pm 3 hari, penepungan dengan dishmill, pelarutan secara maserasi dalam metanol $(1: 3 ; \mathrm{b} / \mathrm{v})$ pada suhu $4^{\circ} \mathrm{C}$ selama $3 \times 24$ jam, pemekatan filtrat yang didapat dengan vacuum rotary evaporator pada suhu $40^{\circ} \mathrm{C}$ kecepatan $100 \mathrm{rpm}$ selama $2,5 \mathrm{jam}$, peniupan dengan gas nitrogen dan diakhiri dengan pengeringan dalam pengering beku.

Hewan coba diabetes didapatkan dengan cara penginduksian tikus dengan streptozotocin. Hewan coba setelah dipuasakan semalam diinjeksi dengan STZ (40 mg/kg BB) yang dilarutkan dalam buffer sitrat $\mathrm{pH} 4,5$ secara intraperitoneal. Tikus coba dinyatakan diabetes bila kadar glukosa darah yang diambil dari bagian ekor dengan glukometer menunjukkan > $200 \mathrm{mg} / \mathrm{dL}$. Perlakuan dalam penelitian ini terdiri dari empat, yaitu: normal, diabetes, diabetes + gliklasid $(30 \mathrm{mg} / \mathrm{kg} \mathrm{BB})$ dan diabetes + ESP $(600 \mathrm{mg} / \mathrm{kg} \mathrm{BB})$ dan perlakuan dilakukan selama 45 hari. Parameter uji diukur pada akhir masa penelitian. Organ uji diambil setelah tikus percobaan dikorbankan dengan cara dislokasi. Prosedur dan pelaksanaan penelitian ini mengikuti komisi etik penelitian (Animal and Use Committee), Universitas Brawijaya (N0. 510-KEP-UB).

Kadar florotanin ditentukan untuk mengukur kadar polifenol ekstrak S. polycystum (Koivikko et al., 2005). Kadar malondialdehid (MDA) berdasar pereaksi thiobarbituric acid (Ohkawa et al., 2005). Kadar SGPT dan SGOT hati diukur untuk menentukan tingkat kerusakan hati (Harris 2005). Pengujian kadar insulin berdasar petunjuk penggunaan kit. Kadar kreatinin darah diukur berdasar metode Jaffe (Syal et al., 2013). Histopatologi hati dan ginjal dianalisis berdasar pewarnaan Hematoksilin dan Eosin.

\section{Analisis Data}

Data yang diperoleh dinyatakan dalam rerata dan simpangan baku. Data dianalisis keragamannya dan perbedaan antar perlakuan diuji dengan metode beda nyata terkecil. Tingkat signifikansi yang digunakan dalam penelitian ini adalah $5 \%$.

\section{HASIL DAN PEMBAHASAN \\ Kadar florotanin}

Florotanin merupakan polimer dari floroglusinol yang merupakan polifenol yang khas dimiliki oleh rumput laut cokelat. Hasil menunjukkan bahwa kandungan florotanin pada ekstrak S. polycystum sebesar $0,6749 \mu \mathrm{g}$ setara floroglusinol/mg ekstrak. Stiger-Pouvreau et al. (2014) menjelaskan bahwa polifenol dalam rumput laut cokelat pada umumnya berbeda dengan polifenol dalam tumbuhan darat dan polifenol ini dikenal sebagai florotanin dimana strukturnya tersusun dari floroglusinol. Kandungan florotanin yang terkandung dalam rumput laut cokelat mencapai 5-15\% dari berat keringnya.

\section{Glukosa darah}

Glukosa darah merupakan salah satu parameter untuk mendiagnosa penyakit diabetes. Individu dinyatakan diabetes bila: (1) kadar gula darah puasa $\geq 126 \mathrm{mg} / \mathrm{dL}$ (puasa: tidak mengkonsumsi sumber kalori selama 8 jam), (2) kadar gula darah 2 jam $\geq 200 \mathrm{mg} / \mathrm{dL}$ pada uji toleransi gula secara oral, dan (3) memiliki gejala-gejala diabetes dengan kadar glukosa darah $\geq 200 \mathrm{mg} / \mathrm{dL}$ (Anonimus, 2011). Kadar glukosa darah tikus percobaan pada akhir percobaan dapat dilihat pada Gambar 1. Hasil analisis data menunjukkan bahwa antar perlakuan menunjukkan ada perbedaan yang signifikan. 


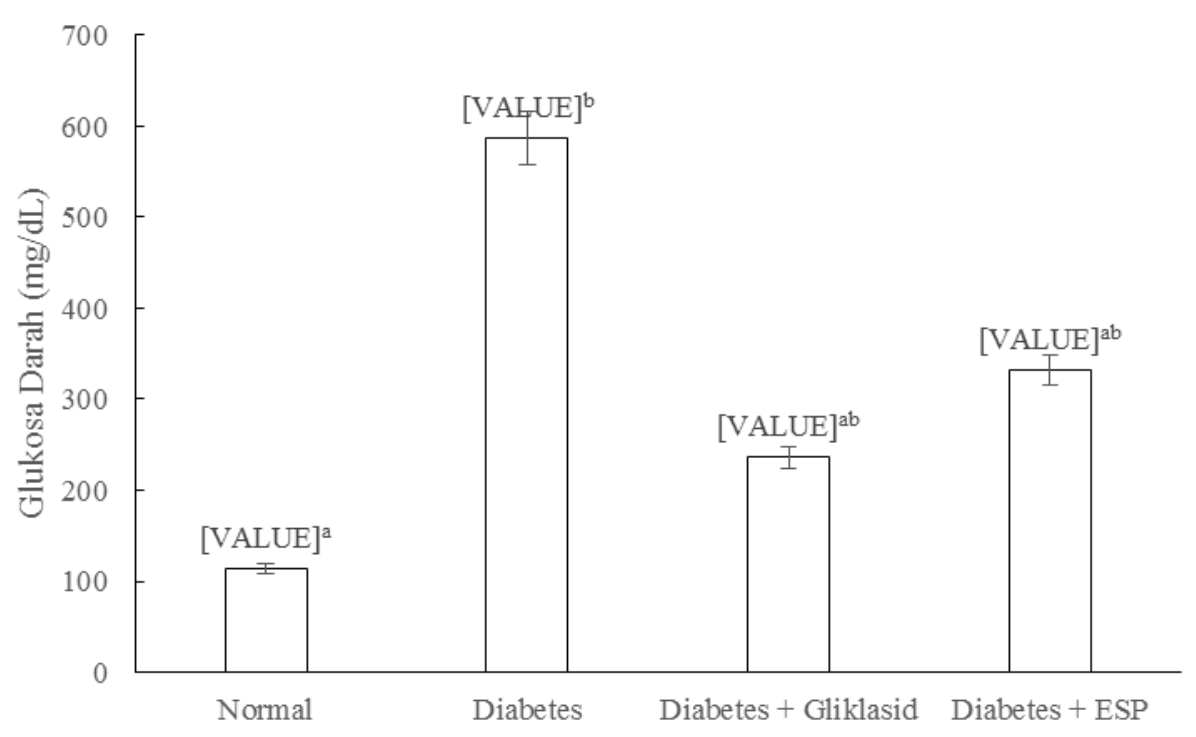

Gambar 1. Kadar glukosa darah tikus normal (A), diabetes (B), diabetes + gliklasid (C) dan diabetes + ESP (D)

Ket: $\quad{ }^{a}=$ berbeda bermakna dengan kelompok diabetes

${ }^{\mathrm{b}}=$ berbeda bermakna dengan kelompok normal

Gambar 1 memperlihatkan bahwa tikus yang mengalami diabetes mengalami hiperglikemik. Huang et al. (2015) menyatakan bahwa kadar glukosa tikus diabetes yang diinduksi STZ menjadi tinggi dikarenakan oleh kerusakan sel $\beta$ pankreas sehingga produksi insulinnya menurun. Apriani et al. (2011) menyatakan bahwa hiperglikemia terjadi akibat defisiensi insulin akibat kerusakan sel $\beta$ atau terjadi penurunan produksi insulin dalam tubuh sehingga glukosa dalam pembuluh darah tidak ada yang dapat masuk dalam sel tubuh dan tetap menumpuk dalam darah (Purnamasari et al., 2014).

Kadar glukosa darah tikus diabetes yang diberi perlakuan dengan gliklasid lebih rendah dibandingkan dengan tikus diabetes. Sarkar et al. (2011) menyatakan bahwa gliklasid dapat menstimulasi sel $\beta$ pankreas yang ada untuk mensekresi insulin. Pelepasan insulin dan interaksinya dengan reseptornya pada sel tubuh akan memberikan sinyal pengambilan glukosa oleh sel tubuh sehingga kadar glukosa dalam darah akan turun.

Penelitian ini juga menunjukkan bahwa kadar glukosa darah tikus diabetes yang diberi perlakuan dengan ekstrak $S$. polycystum lebih rendah dibanding tikus kelompok diabetes meski tidak serendah kadar glukosa darah tikus diabetes yang diberi perlakuan dengan gliklasid. Kang et al. (2013) menunjukkan bahwa tikus diabetes yang diberi florotanin kadar glukosa darahnya menurun. Rengasamy et al. (2014) menyatakan bahwa florotanin memiliki kemampuan sebagai agen antihiperglikemik karena kemampuannya dalam menghambat aktivitas enzim $\alpha$-glukosidase dan $\alpha$ amilase. Penghambatan enzim tersebut menyebabkan hidrolisis polisakarida makanan menjadi glukosa tidak maksimal sehingga ketersediaan glukosa yang diserap menjadi lebih terbatas. Sementara itu Kim dan Kim (2012) menyatakan bahwa penurunan glukosa darah pada tikus diabetes oleh rumput laut cokelat dari spesies Ecklonia cava terkait pada kemampuan polifenolnya untuk menginduksi sel $\beta$ pankreas dalam mensekresi insulinnya.

\section{Kadar insulin}

Insulin adalah hormon yang disekresi oleh sel $\beta$-pankreas dan berfungsi untuk mengaktifkan ambilan glukosa oleh sel sehingga kadar glukosa dalam darah tetap terkendali dan normal dalam kisarannya (Wilcox, 2005). Kadar insulin darah tikus pada semua kelompok pada akhir percobaan 
dapat dilihat pada Gambar 2. Hasil analisis data menunjukkan bahwa antar perlakuan menunjukkan ada perbedaan yang signifikan.

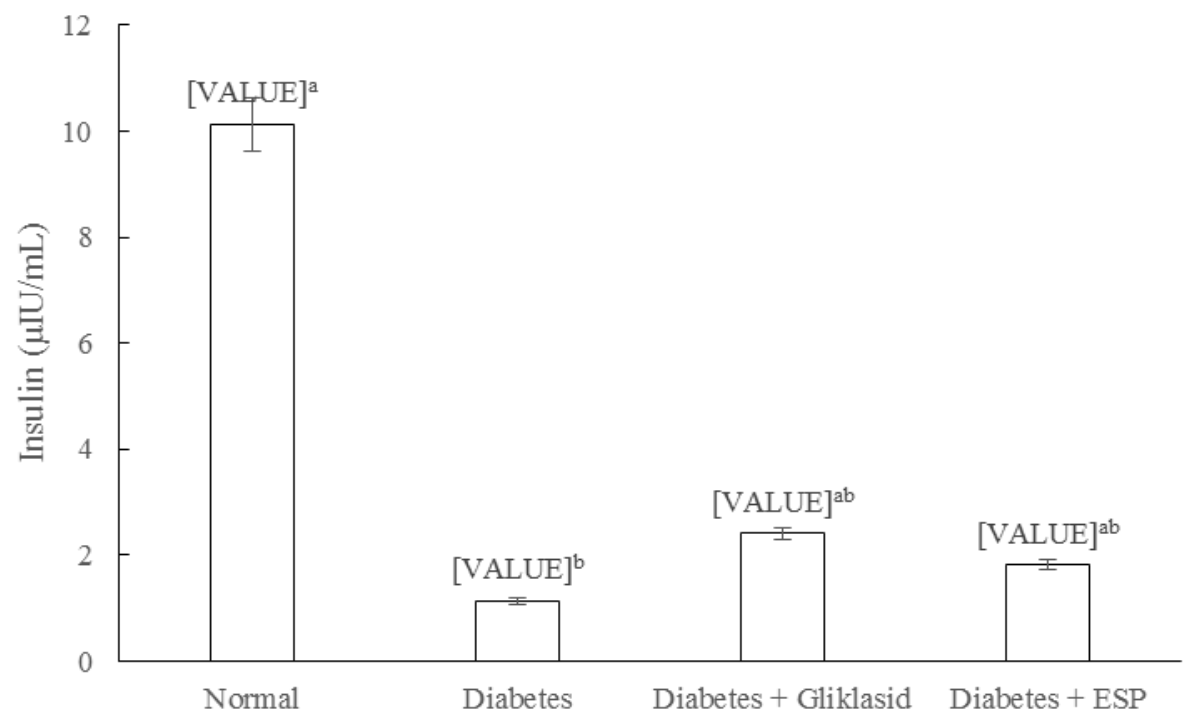

Gambar 2. Kadar insulin darah tikus normal (A), diabetes (B), diabetes + gliklasid (C) dan diabetes + ESP (D)

Ket: $\quad{ }^{a}=$ berbeda bermakna dengan kelompok diabetes

${ }^{\mathrm{b}}=$ berbeda bermakna dengan kelompok normal

Gambar 2 memperlihatkan bahwa kadar insulin tikus kelompok diabetes paling rendah diantara kelompok perlakuan lainnya. Hal ini dimungkinkan karena efek sitotoksik dari STZ pada sel $\beta$ pankreas. STZ adalah metil nitrosurea yang sangat mudah berinteraksi dengan glukosa untuk membentuk turunan glukosamin. Senyawa ini bersifat hidrofil dan mudah masuk ke dalam sel $\beta$ pankreas melalui glucose trasporter 2. Alkilasi senyawa ini dengan inti sel $\beta$-pankreas pada pulau Langerhans mengakibatkan fragmentasi DNA sel ini hingga sel mengalami nekrosis dan akibatnya sel $\beta$-pankreas kehilangan fungsinya sebagai penghasil dan pensekresi insulin (Eleazu et al., 2013).

Kadar insulin darah tikus diabetes yang diberi perlakuan dengan gliklasid lebih tinggi dibanding tikus diabetes kontrol. Gliklasid tergolong obat penurun glukosa darah oral karena kemampuannya dalam meningkatkan pemanfaatan glukosa, dan menurunkan pembentukan glukosa dari hati serta mampu meningkatkan jumlah dan sensitivitas insulin reseptor (Nasry et al., 2013). Meningkatnya kadar insulin sangat berkaitan dengan peningkatan sekresi insulin oleh sel $\beta$-pankreas. Ikatan gliklasid ke reseptor sulfonylurea sel $\beta$-pankreas (SUR1) berakibat pada penutupan saluran $\mathrm{K}^{+}$yang sensitive ATP. Penutupan saluran ini berakibat pada depolarisasi sel $\beta$-pankreas yang selanjutnya akan meningkatkan eksositosis insulin dari granulanya (Sarkar et al. 2011).

Hasil penelitian ini juga menunjukkan bahwa kadar insulin darah tikus diabetes yang diberi perlakuan dengan ekstrak $S$. polycystum lebih tinggi dibanding tikus diabetes kontrol meskipun tidak setinggi yang diberi perlakuan dengan gliklasid. Hal ini dimungkinkan karena senyawa polifenol dalam ekstrak $S$. polycystum mampu menginduksi sel $\beta$-pankreas untuk mensekresi insulin. Hajiaghaalipour et al. (2015) menjelaskan bahwa polifenol mempunyai kemampuan meningkatkan sekresi insulin melalui insulin signaling pathway dengan meningkatkan ketersediaan glucose transporter 2 pada sel $\beta$-pankreas.

\section{Kadar malondialdehid}

Malondialdehid (MDA) merupakan salah satu produk akhir dari proses peroksidasi lipid akibat adanya reaktif oksigen spesi terhadap membran sel. Hidroksiperoksida lipid bersifat tidak stabil dan dapat terurai menjadi aldehid terutama MDA, sehingga MDA dapat digunakan sebagai indikator pengukuran radikal bebas dalam tubuh (Ullah et al., 2015). Kadar malondialdehid organ tikus 
percobaan pada akhir percobaan dapat dilihat pada Tabel I. Hasil analisis data menunjukkan bahwa antar perlakuan menunjukkan ada perbedaan.

Tabel I. Kadar malondialdehid pada hati dan ginjal tikus normal, diabetes, diabetes + gliklasid dan diabetes + ESP

\begin{tabular}{lcc}
\hline Kelompok & $\begin{array}{c}\text { MDA hati } \\
(\mathbf{n m o l} / \mathbf{m L})\end{array}$ & $\begin{array}{c}\text { MDA ginjal } \\
(\mathbf{n m o l} / \mathbf{m L})\end{array}$ \\
\hline Normal & $22,32 \pm 2,3^{\mathrm{a}}$ & $59,5 \pm 3,3^{\mathrm{a}}$ \\
Diabetes & $93,32 \pm 4,3^{\mathrm{b}}$ & $202,2 \pm 33,3^{\mathrm{b}}$ \\
Diabetes + Gliklasid & $30,62 \pm 3,4^{\mathrm{ab}}$ & $127,5 \pm 13,7^{\mathrm{ab}}$ \\
Diabetes + ESP & $41,32 \pm 2,2^{\mathrm{ab}}$ & $133,4 \pm 21,7^{\mathrm{ab}}$ \\
\hline
\end{tabular}

Ket: ESP $=$ Ekstrak $S$. polycystum

${ }^{\mathrm{a}}=$ berbeda bermakna dengan kelompok diabetes

${ }^{\mathrm{b}}=$ berbeda bermakna dengan kelompok normal

Tabel I memperlihatkan bahwa kadar MDA hati dan ginjal tikus coba diabetes paling tinggi diantara kelompok perlakuan. Hal ini menunjukkan bahwa hiperglikemia pada hewan coba diabetes telah mengakibatkan stres oksidatif pada organ-organ tersebut. Saat stress oksidatif, radikal bebas dalam sel akan lebih dominan dari antioksidan enzim hingga radikal bebas yang tidak ternetralisir ini bereaksi dengan asam-asam lemak tak jenuh pada membran sel yang berakibat terbentuknya produk lipid peroksidasi, diantaranya adalah MDA (Ayala et al., 2014).

Tabel I memperlihatkan bahwa kadar MDA hati dan ginjal tikus diabetes yang diberi perlakuan dengan gliklasid lebih rendah dibanding tikus diabetes kontrol. Gliklasid diketahui sebagai obat hipoglikemik oral yang dapat bertindak sebagai antioksidan. Aktivitas antioksidan obat ini adalah kemampuannya dalam mengurangi jumlah dan kereaktivan radikal hidroksil $\left(\mathrm{OH}^{-}\right)$. Pengurangan kereaktivan radikal bebas ini berakibat pada penghambatan atau bahkan penghentian reaksi lipid peroksidasi terhadap membran sel sehingga pembentukan MDA sebagai marker lipid peroksidasi akan menurun atau bahkan tidak terjadi (Memisogullari et al. 2008).

Berdasarkan hasil penelitian menunjukkan bahwa kadar MDA hati dan ginjal tikus diabetes yang diberi perlakuan dengan ekstrak $S$. polycystum lebih rendah dibanding tikus diabetes kontrol meskipun nilainya tidak sama dengan tikus diabetes yang diberi perlakuan dengan gliklasid. Hasil ini menunjukkan bahwa pemberian ESP mampu mengurangi laju kereaktivan radikal bebas terhadap kerusakan hepatosit tikus diabetes. Penurunan kadar radikal bebas seringkali dikaitkan dengan adanya penurunan jumlah dan kereaktivan radikal bebas oleh florotanin. Senyawa bioaktif ini diketahui memiliki banyak proton yang mudah membentuk ikatan hidrogen dengan radikal bebas. Terdapat dua mekanisme polifenol sebagai antioksidan, yaitu 1) pendonoran atom hidrogen dari gugus hidroksil fenol, dan 2) pemindahan elektron tunggal polifenol ke radikal bebas untuk membentuk kation radikal stabil (Firdaus, 2013). Penurunan radikal bebas ini berakibat pada penurunan kejadian lipid peroksidasi sehingga kadar MDA yang terbentuk menurun (Firdaus, 2011).

\section{Kadar SGPT dan SGOT}

SGPT dan SGOT merupakan enzim dalam hati yang terdapat didalam sel parenkim hati dimana kedua enzim tersebut akan meningkat kadarnya di jaringan bila ada kerusakan pada hepatosit. Kadar SGPT dan SGOT hati tikus percobaan pada akhir percobaan dapat dilihat pada Tabel II. Hasil analisis data menunjukkan bahwa antar perlakuan menunjukkan ada perbedaan signifikan diantara kelompokkelompok perlakuan. 
Tabel II. Kadar SGPT, SGOT dan kreatinin pada tikus normal, diabetes, diabetes + gliklasid dan diabetes + ESP

\begin{tabular}{lccc}
\hline Kelompok & $\begin{array}{c}\text { SGPT } \\
(\mathbf{U} / \mathbf{L})\end{array}$ & $\begin{array}{c}\text { SGOT } \\
(\mathbf{U} / \mathbf{L})\end{array}$ & $\begin{array}{c}\text { Kreatinin } \\
(\mathbf{m g} / \mathbf{d L})\end{array}$ \\
\hline Normal & $21,2 \pm 1,9^{\mathrm{a}}$ & $50,6 \pm 3,3^{\mathrm{a}}$ & $0,30 \pm 0,01^{\mathrm{a}}$ \\
Diabetes & $481,8 \pm 7,8^{\mathrm{b}}$ & $502,0 \pm 12,3^{\mathrm{b}}$ & $0,75 \pm 0,07^{\mathrm{b}}$ \\
Diabetes + Gliklasid & $65,2 \pm 4,3^{\mathrm{ab}}$ & $117,0 \pm 8,8^{\mathrm{ab}}$ & $0,35 \pm 0,02^{\mathrm{ab}}$ \\
Diabetes + ESP & $114,0 \pm 7,9^{\mathrm{ab}}$ & $154,4 \pm 7,6^{\mathrm{ab}}$ & $0,48 \pm 0,03^{\mathrm{ab}}$ \\
\hline
\end{tabular}

Ket: ESP = Ekstrak $S$. polycystum

${ }^{\mathrm{a}}$ = berbeda bermakna dengan kelompok diabetes

${ }^{\mathrm{b}}=$ berbeda bermakna dengan kelompok normal

Tabel II memperlihatkan bahwa kadar SGPT dan SGOT hati tikus yang mengalami diabetes paling tinggi diantara kelompok perlakuan. Hasil ini menunjukkan bahwa tingkat kerusakan hepatosit akibat radikal bebas lebih dominan terjadi pada tikus diabetes. Peningkatan kadar SGPT dan SGOT merupakan pertanda dari kerusakan membran sel akibat adanya lipid peroksidasi oleh spesies oksigen reaktif pada fase stres oksidatif. Suarsana et al., (2011), menyatakan bahwa hiperglikemia menyebabkan proses auto oksidasi glukosa yang menghasilkan radikal bebas hidroksil, dimana radikal bebas ini dapat berinteraksi dengan lipid membran. Interaksi ini mengakibatkan terjadinya reaksi peroksidasi lipid sehingga membran akan mengalami perubahan struktur dan kehilangan fungsinya.

Tabel II memperlihatkan bahwa kadar SGPT dan SGOT hati tikus diabetes yang diberi perlakuan dengan gliklasid lebih rendah dibanding tikus diabetes kontrol. Hasil ini menunjukkan bahwa gliklasid mampu mencegah kerusakan hepatosit akibat radikal bebas karena diabetes. Memisogullari et al. (2008) menyatakan bahwa obat penurun glukosa darah ini berkemampuan mengurangi jumlah dan menurunkan kereaktivan hidroksil radikal, dimana radikal oksigen inilah yang paling reaktif berinteraksi dengan membran sel. Penurunan jumlah radikal ini berarti menurunkan tingkat kerusakan sel, jaringan dan organ tubuh, sehingga aktivitas kedua enzim tersebut juga menurun.

Hasil penelitian ini menunjukkan bahwa kadar SGPT dan SGOT hati tikus diabetes yang diberi perlakuan dengan ekstrak $S$. polycystum lebih rendah dibanding tikus diabetes kontrol meskipun kadarnya berbeda dengan tikus yang diberi perlakuan dengan gliklasid. Hasil ini menunjukkan bahwa pemberian ESP mampu mengurangi laju kereaktivan radikal bebas terhadap kerusakan hepatosit tikus diabetes. ESP diketahui mengandung polifenol yaitu suatu bioaktif yang mempunyai aktivitas sebagai antioksidan sehingga akan menurunkan radikal bebas yang ada didalam hepatosit (Firdaus, 2013).

\section{Kadar kreatinin}

Kreatinin merupakan hasil pemecahan keratin fosfat otot dan keberadaannya dalam darah digunakan sebagai parameter menurunnya fungsi ginjal yaitu penurunan laju penyaringan oleh glomerulus (Glomerulus Filtration Rate $=$ GFR). Pada kondisi normal kreatinin ini akan reabsorbsi oleh glomerulus ginjal (Mohabbati-Kalejahi et al. 2012). Kadar kreatinin tikus percobaan pada akhir percobaan dapat dilihat pada Tabel II. Hasil analisis data menunjukkan bahwa antar perlakuan menunjukkan ada perbedaan yang signifikan.

Tabel II memperlihatkan bahwa kadar kreatinin tikus diabetes paling tinggi diantara kelompok perlakuan. Hasil ini menunjukkan bahwa tingkat penurunan fungsi reabsorbsi glomerulus lebih besar terjadi pada kelompok diabetes. Hiperglikemik dapat mengakibatkan glomerulus mengalami stres oksidatif. Keadaan ini mengakibatkan kerusakan pada struktur glomerulus hingga glomerulus kehilangan fungsinya (Giacco and Brownlee, 2010).

Kadar kreatinin tikus diabetes yang diberi perlakuan dengan gliklasid lebih rendah dibanding hewan coba diabetes kontrol. Hasil ini menunjukkan bahwa penggunaan gliklasid mampu mencegah gangguan fungsi filtrasi glomerulus akibat radikal bebas. Kemampuan gliklasid dalam menurunkan kadar dan reaktivitas hidroksil radikal berakibat mencegah kerusakan struktur glomerulus lebih meluas terjadi pada tikus diabetes (Memisogullari et al. 2008). 
Kadar kreatinin tikus diabetes yang diberi perlakuan dengan ekstrak $S$. polycystum lebih rendah dibanding tikus diabetes kontrol walau tidak serendah yang diperlakukan dengan gliklasid. Hasil ini menunjukkan bahwa pemberian ESP juga mampu mencegah gangguan fungsi filtrasi glomerulus akibat radikal bebas pada tikus diabetes. Kandungan polifenol dalam ESP telah berkontribusi sebagai penurun kadar dan reaktivitas radikal bebas, sehingga mencegah kerusakan glomerulus tidak lebih parah bila tidak diberi ESP (Firdaus, 2013).

\section{Gambaran mikrokopik hati dan ginjal}

Gambaran mikrokopik hati yang normal adalah sel-sel hati tidak mengalami nekrosis dan inti sel terlihat sangat padat serta tidak terdapat sel-sel yang mengalami perlemakan. Gambaran mikrokopik ginjal yang normal memiliki kapiler, glomerulus, kapsul epitel ganda yang disebut kapsula Bowman dan diantara kapsula tersebut terdapat ruang Bowman's. Gambaran mikrokopik hati dan ginjal tikus percobaan pada akhir percobaan dapat dilihat pada Gambar 3 dan 4. Hasil analisis data menunjukkan bahwa antar perlakuan menunjukkan ada perbedaan.
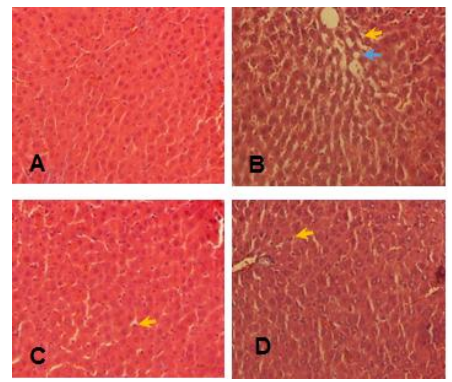

Gambar 3. Mikrokopik hati tikus normal (A), diabetes (B), diabetes + gliklasid (C) dan diabetes + EPS (D)

Ket: $\quad+=$ sel nekrosis $\leftarrow=$ sel perlemakan

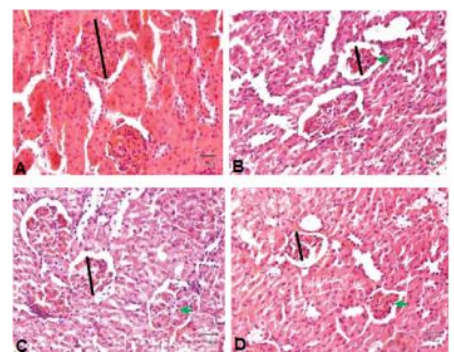

Gambar 4. Mikrokopik ginjal tikus normal (A), diabetes (B), diabetes + gliklasid (C) dan diabetes + EPS (D)

$$
\text { Ket: } \leftarrow=\text { sel nekrosis } \quad \text { = diameter glomerulus }
$$

Gambar 3 memperlihatkan bahwa tingkat nekrosis dan perlemakan hati tikus coba yang mengalami diabetes paling dominan dibanding kelompok perlakuan lainnya. Gambar 4 memperlihatkan bahwa pengkerutan glomerulus dan nekrosis selnya pada tikus diabetes paling banyak dibanding kelompok perlakuan lainnya. Hal ini menunjukkan bahwa radikal bebas yang terbentuk oleh hiperglikemik telah menyebabkan kerusakan sel. Hal ini sesuai yang dinyatakan Firdaus (2017) bahwa manifestasi DM dapat menimbulkan terjadinya berbagai kerusakan sel yang mengindikasi adanya akumulasi radikal bebas dalam tubuh. Jadi dapat dikatakan bahwa ketika radikal bebas dalam tubuh meningkat, maka akan meningkatkan kerusakan sel tubuh.

Gambar 3 dan 4 memperlihatkan bahwa tingkat kerusakan hati dan ginjal tikus diabetes yang diperlakukan dengan gliklasid lebih rendah dibanding tikus diabetes kontrol. Gliklasid adalah Obat 
Hipoglikemik Oral (OHO) golongan sulfonilurea yang bekerja menstimulasi sel beta pankreas untuk melepaskan insulin yang tersimpan sehingga glukosa darah yang ada dalam pembuluh darah masuk ke dalam sel. Penurunan glukosa darah ini berakibat pada penurunan pembentukan radikal bebas sehingga kerusakan hepatosit pada penyandang diabetes dapat dikurangi. Hal ini dimungkinkan karena kadar radikal bebas yang dapat mengabstraksi asam lemak tak jenuh rantai panjang membran sel lebih sedikit sehingga kerusakan selpun menjadi lebih sedikit pula (Memisogullari et al. 2008).

Gambar 3 dan 4 memperlihatkan bahwa tingkat kerusakan hati dan ginjal tikus diabetes yang diberi perlakuan dengan ekstrak $S$. polycystum lebih rendah dibanding tikus diabetes kontrol meskipun tidak serendah yang diberi perlakuan dengan gliklasid. Hal ini dimungkinkan oleh adanya aktivitas pengurunan glukosa dan pengurangan kadar radikal bebas oleh polifenol dalam ESP. S. polycystum merupakan salah satu rumput laut yang kaya akan polifenol. Senyawa ini telah diketahui mampu menurunkan glukosa darah pada penyandang diabetes. Penurunan ini berkontribusi pada penurunan terbentuknya radikal bebas sehingga peroksidasi lemak pada membran sel menjadi rendah. Penurunan ini mencegah kerusakan sel-sel organ penyandang diabetes dan pada akhirnya mencegah terjadinya penyakit komplikasi diabetes (Firdaus et al., 2010).

\section{KESIMPULAN}

Ekstrak S. polycystum dapat mengurangi kerusakan fungsi dan struktur hati dan ginjal pada tikus diabetes melitus.

\section{UCAPAN TERIMAKASIH}

Penelitian ini didanai oleh Kementerian Riset, Teknologi dan Pendidikan Tinggi, Republik Indonesia, melalui skim Penelitian Hibah Berbasis Kompetensi tahun Anggaran 2016 dengan nomer kontrak 33/SP2H/LT/DRPM/II/2016.

\section{DAFTAR PUSTAKA}

Anonimus, 2011. Diagnosis and Classification of Diabetes Mellitus. Diabetes Care, 34, 62-69.

Apriani. N., Suhartono. E., Akbar. I.Z. 2011. Korelasi kadar glukosa darah dengan kadar Advanced Oxidation Protein Product (AOPP) tulang pada tikus model hiperglikemia. Jurnal Kesehatan Masyarakat, 11, 48-55.

Ayala. A., Muñoz. M.F., Argüelles. S. 2014. Review Article: Lipid Peroxidation: Production, Metabolism, and Signaling Mechanisms of Malondialdehyde and 4-Hydroxy-2-Nonenal. Oxidative Medicine and Cellular Longevity, Article ID 360438, 31.

Bahadoran. Z., Mirmiran. P. and Azizi. F. 2013. Dietary polyphenols as potential nutraceuticals in management of diabetes: a review. Journal of Diabetes \& Metabolic Disorders, 12, 43-52.

Barde. S.R., Sakhare. R.S., Kanthale. S.B., Chandak. P.G., Jamkhande. P.G. 2015. Marine bioactive agents: a short review on new marine antidiabetic compounds. Asian Pacific Journal of Tropical Disease, 5(Suppl 1), S209-S213.

Eleazu. C.O., Eleazu K.C., Chukwuma. S., Essien. U.N. 2013. Review of the mechanism of cell death resulting from streptozotocin challenge in experimental animals, its practical use and potential risk to humans. Journal Diabetes Metabolisme Disordorder, 12, 60.

Firdaus. M. 2011. Aktivitas Antioksidan Ekstrak Rumput Laut Coklat (Sargassum echinocarpum) sebagai Pencegah Disfungsi Sel Endotelium Aorta Tikus Diabetes Melitus. Disertasi. Institut Pertanian Bogor, Bogor.

Firdaus. M. 2013. Indeks Aktivitas Antioksidan Ekstrak Rumput Laut Coklat (Sargassum aquifolium). Jurnal Pengolahan Hasil Perikanan Indonesia, 16, 42-47.

Firdaus. M. 2017. Diabetes dan rumput laut cokelat. UB Press. Malang.159.

Fraga. C.G., Galleano. M., Verstraeten. S.V., Oteiza. P.I. 2010. Basic biochemical mechanisms behind the health benefits of polyphenols. Molecular Aspects of Medicine, 31, 435-445.

Giacco. F. and Brownlee. M. 2010. Oxidative stress and diabetic complications. Circulation Research, 107(9), 1058-1070. 
Hajiaghaalipour. F., Khalilpourfarshbafi. M., Arya. A. 2015. Modulation of Glucose Transporter Protein by Dietary Flavonoids in Type 2 Diabetes Mellitus. International Journal of Biological Sciences. 11(5): 508-524.

Harris. E.H. 2005. Elevated Liver Function Tests in Type 2 Diabetes. Clinical Diabetes, 23, 115-119.

Huang. D., Jing. Y., Chen. W., Yao. F., Huang. G., Suna. L. 2015. Evaluation of Hypoglycemic Effects of Polyphenols and Extracts from Penthorum chinense. Journal of Ethnopharmacology, $107,15-21$.

Jay. D., Hitomi, H., Griendling. K.K. 2006. Oxidative stress and diabetic cardiovascular complications. Free Radical Biology \& Medicine, 40, 183 - 192.

Kang. M., Chung. H., Kim. J., Son. B.W., Jung. H.A., Choi. J.S. 2013. Dieckol isolated from brown seaweed Ecklonia cava attenuates type II diabetes in $\mathrm{db} / \mathrm{db}$ mouse model. Food and Chemical Toxicology, 53, 294-298.

Kim. M.-J., Kim. H. K., 2012. Insulinotrophic and hypolipidemic effects of Ecklonia cava in streptozotocin-induced diabetic mice. Asian Pacific Journal of Tropical Medicine, 374-379.

Koivikko. R., Loponen. J., Honkanen, Jormalainen. V. 2005. Contents of Soluble, Cell-Wall-Bound and Exuded Phlorotannins in The Brown Alga Fucus vesiculosus, with Implications on Their Ecological Function. Journal of Chemical Ecology, 31, 195-212.

Kuyvenhoven. J.P. and Meinders. A.E. 1999. Oxidative stress and diabetes mellitus: Pathogenesis of long-term complications. European Journal of Internal Medicine, 10, 9-19.

Lee S.-H., and Jeon. Y.-J. 2013. Anti-diabetic effects of brown algae derived phlorotannins, marine polyphenols through diverse mechanisms, Fitoterapia, 86, 129-136.

Memişoğullari. R., Türkeli M., Bakan E. Akçay F. 2008. Effect of Metformin or Gliclazide on Lipid Peroxidation and Antioxidant Levels in Patients with Diabetes Mellitus. Turkish Journal of Medical Science, 38 (6), 545-548.

Mohabbati-Kalejahi. E., Azimirad. V., Bahrami. M., Ganbari. A. 2012. A review on creatinine measurement techniques. Talanta, 97, 1-8.

Ohkawa H, Ohishi N, Yagi K. 1979. Assay for lipid peroxides in animal tissues by thiobarbituric acid reaction. Analytical Biochemistry, 95: 351-358.

Purnamasari. D., Waspadji. S., Adam. J.M.F., Rudijanto. A., Tahapary. D. 2013. Indonesian Clinical Practice Guidelines for Diabetes in Pregnancy. JAFES, 28, 9-13.

Rengasamy. K.R.R., Kulkarni. M., Strik. W., Staden. J. 2014. Advances in algal drug research with emphasis on enzyme inhibitors. Biotechnology Advances, 40, 10-21.

Sarkar. A., Tiwari. A., Bhasin. P.S., Mitra. M. 2011. Pharmacological and Pharmaceutical Profile of Gliclazide: A Review. Journal of Applied Pharmaceutical Science, 1, 11-19.

Stiger-Pouvreau. V., Jégou. C., Cérantola S., Guérard F., Le Lann. K. 2014. Phlorotannins in Sargassaceae Species from Brittany (France): Interesting Molecules for Ecophysiological and Valorisation Purposes. Advances in Botanical Research, 47, 379-411.

Suarsana. I.N., Wresdiyati. T., Suprayogi. A. 2013. Respon stres oksidatif dan pemberian iso flavon terhadap aktivitas enzim superoksida dismutase dan peroksidasi lipis pada hati tikus. JITV, 18, 45-54.

Syal. K., Banerjee. D., Srinivasan A. 2013. Creatinine estimation and interference. Indian Journal of Clinical Biochemistry, 28, 210-211.

Ullah. A., Khan. A., Khan. I. 2015. Diabetes mellitus and Oxidative Stress: A Concise Review. Saudi Pharmaceutical Journal, 2, 1-8.

Wilcox. G. 2005. Insulin and Insulin Resistance. Clinical Biochemistry Review, 26 (2), 19-39. 